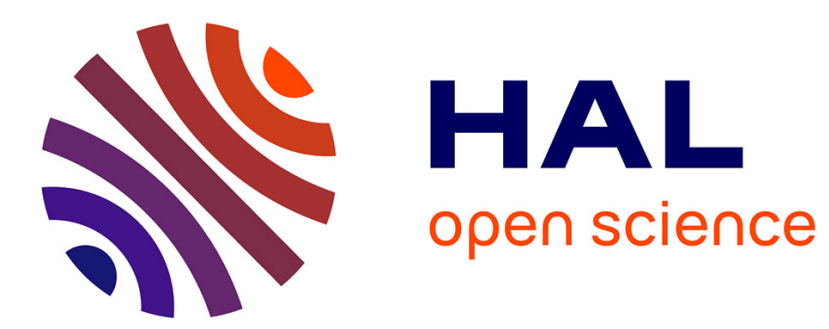

\title{
Les conférences de Siem Reap
}

Christophe Pottier

\section{To cite this version:}

Christophe Pottier. Les conférences de Siem Reap. Bulletin de l'Ecole française d'Extrême-Orient, 2003, 90, pp.487-490. 10.3406/befeo.2007.6074 . hal-03026029

\section{HAL Id: hal-03026029 \\ https://hal.science/hal-03026029}

Submitted on 23 Feb 2022

HAL is a multi-disciplinary open access archive for the deposit and dissemination of scientific research documents, whether they are published or not. The documents may come from teaching and research institutions in France or abroad, or from public or private research centers.
L'archive ouverte pluridisciplinaire HAL, est destinée au dépôt et à la diffusion de documents scientifiques de niveau recherche, publiés ou non, émanant des établissements d'enseignement et de recherche français ou étrangers, des laboratoires publics ou privés. 


\section{Les conférences de Siem Reap}

Christophe Pottier

\section{Citer ce document / Cite this document :}

Pottier Christophe. Les conférences de Siem Reap. In: Bulletin de l'Ecole française d'Extrême-Orient. Tome 90-91, 2003. pp. 487-490;

doi : https://doi.org/10.3406/befeo.2003.3627

https://www.persee.fr/doc/befeo_0336-1519_2003_num_90_1_3627

Fichier pdf généré le 08/11/2019 


\title{
Les conférences de Siem Reap
}

\author{
Christophe POTTIER
}

Depuis quelques années, le site d'Angkor accueille une communauté de chercheurs en pleine expansion au sein d'institutions permanentes étrangères ou cambodgiennes, telle APSARA, l'établissement public en charge du site qui emploie désormais de nombreux jeunes cadres nationaux. Les diverses équipes d'experts impliqués dans la restauration ou la recherche à Angkor et les étudiants qui y font leur terrain produisent ainsi régulièrement de nouvelles informations qui concourent à l'élaboration d'une meilleure connaissance du site. Par ailleurs, les monuments d'Angkor constituent évidemment une remarquable destination touristique pour nombre de personnes qui, si elles ne sont pas impliquées dans les études khmères, n'en ont pas moins des connaissances et des compétences dont le partage peut être utile à la communauté scientifique locale.

Depuis près de dix ans, les réunions bi-annuelles du Comité international de coordination pour Angkor ont constitué un forum ponctuel où se réunissaient les différentes équipes pour soumettre leurs projets et présenter leurs travaux aux autorités cambodgiennes et à l'Unesco, qui assure le secrétariat de ce comité coprésidé par la France et le Japon. Il manquait toutefois un lieu moins formel et des occasions plus souples pour favoriser le développement des échanges scientifiques à l'intérieur même de la communauté engagée sur le site d'Angkor, dans une ambiance assagie après dix années d'activités parfois conflictuelles.

C'est dans cet esprit qu'a été lancée durant l'été 2002 une série de causeries « informelles». Aucun calendrier ne guide ces interventions, le principe étant justement de tenir ces conférences à l'occasion du passage à Siem Reap des intervenants et de leur disponibilité.

Plus d'une quarantaine de chercheurs, de statuts variés et de nationalités diverses, ont bien voulu se prêter à l'exercice et nous faire l'honneur de donner dans la langue de leur choix une conférence informelle sur un thème qui leur est cher, sur de récentes recherches ou sur leurs travaux en cours. Si un bon tiers des exposés concernait l'archéologie, les sujets ont aussi porté sur l'architecture, l'iconographie, l'épigraphie, la linguistique, la muséographie et l'ethnologie, témoignant de la pluridisciplinarité des approches. Ces conférences d'une durée d'une heure environ sont suivies de questions et souvent de discussions qui se poursuivent lors du dîner offert au conférencier.

Ces conférences se sont tenues pendant plus d'un an dans la bibliothèque même du centre de l'EFEO à Siem Réap. Le bâtiment de l'EFEO récemment rénové dispose désormais d'une salle de réunion mieux adaptée pour accueillir une assistance qui varie de 20 à 80 personnes. Nous souhaitons néanmoins conserver à ces conférences leur caractère pluridisciplinaire et informel, privilégiant les échanges directs, même éphémères, plutôt que l'élaboration de textes ou de publications qui freinerait la spontanéité et la disponibilité des conférenciers.

Liste des conférences 2002

9 juillet: Geoffrey BENJAMIN (professeur associé, Nanyang Technological University, Singapore), The Austric Marchland: the Malay Peninsula in a Mainland Context.

16 juillet : Claire MERLEAU-PONTY (chargée de cours à l'École du Louvre - Responsable du service d'action culturelle des Arts d'Afrique et d'Océanie, Musée des Arts africains et océaniens), Approche muséographique du musée national de Phnom Penh. 
19 juillet: Georges CONDOMINAS (directeur d'études à l'EHESS), Recherche et sauvegarde du patrimoine immatériel.

23 août: Claire DARD-TERNISIEN (étudiante à l'Institut national du Patrimoine, section restauration), Bois polychromes : étude technique et restauration.

27 août: Claude JACQUES (directeur d'études à l'EPHE), Les inscriptions du Cambodge ancien : le cas de la grande stèle du Prah Khan d'Angkor (K. 908).

2 septembre: Sachchidanand SAHAI (Fellow at Indian Institute of Advanced Study, Simla), Interpreting Devaraja: Implications for Khmer Civilization.

29 novembre: Pierre-Yves MANGUIN (EFEO), From Funan (Mekong Delta) to Tarumanagara (West Java): the Archaeology of the Early States of Southeast Asia.

3 décembre : Chun-fang YU (Rutgers University), Kuan-Yin: the Chinese Transformation of Avalokitesvara.

Liste des conférences 2003

10 janvier: Dan PENNY (post-doctorant, University of Sydney), The application of palaeoenvironment techniques to the study of Khmer history.

17 janvier: Mike BARBETTI (directeur, NWG Macintosh Centre for Quaternary Dating, University of Sydney), Radiocarbon dating: how old is your wooden artefact, piece of charcoal, or skeleton?

27 janvier : Alexandra HAENDEL (doctorante, School of Oriental and African Studies, University of London), East Mebon and Pre Rup, two tenth century temples.

12 février : Roland FLETCHER (professeur associé, département d'archéologie, University of Sydney), The Greater Angkor Project 2002: a review.

17 février: Rethy K. CHHEM (professeur associé, National University of Singapore), Investigating the human past using medical high technology: skeletons from Prei Khmeng.

25 février: Hélène LEGENDRE DE KONINCK (chercheur invité, université de Montréal), Les grands bas-reliefs du temple d'Angkor Vat.

3 mars: Gérard DifFLOTH (EFEO), Mon-Khmer languages, myths and reality.

21 mars: Hisao ARAHI (Research fellow, Institute of Asian Culture, Sophia University), Architectural reading of Banteay Kdei temple: Study on the relative chronology of the architectural monuments.

26 mars : Hedwige Multzer O'NAGHTEN (doctorante, université Paris-III), L'organisation du royaume de Jayavarman VII.

22 mai : AN Sopheap \& So Peang (APSARA), Archéologie et développement : les fouilles préventives récentes à Angkor.

10 juin : Matti KUMMU (doctorant, Helsinki University of Technology - MRCS/WUP-FIN Tonle Sap Modelling Project), Waters of Angkor. Modelling the cultural hydraulics and natural hydrology.

17 juillet : Christophe POTTIER (EFEO), On the city's edges, the territory of Angkor.

24 juillet: Ernelle BERLIET (doctorante, Lyon-II/Paris-III, boursière de l'EFEO), Historical geography and urbanisation in Burma (2nd century BC - end of 13th century $A D)$.

15 août : Vincent LEFÈVRE (conservateur, musée national des Arts asiatiques - Guimet), La question du portrait au Tamil Nadu. 
21 août: Vittorio ROVEDA (chercheur indépendant), Iconography and narratology in Khmer art.

27 août : Gérard Diffloth (EFEO), "Mon-Khmer", what does it mean?

4 septembre: Jaro PONCAR (German Apsara Conservation Project / professeur, University of Applied Sciences, Cologne), Treasures of Asian architecture - From the Himalayas to Angkor. Twenty-two years of photographic documentation.

6 septembre (en coll. avec le Centre d'études khmères) : Vasundhara FILLIOZAT (Indian Gandhi National Center for the Arts, New Delhi) \& Pierre-Sylvain FILliozAT (membre de l'Institut, directeur d'études à l'EPHE), Sources for the study of Khmer and Indian temples.

8 septembre: Heng Than \& KHIEU Chan (APSARA), Prei Khmeng 2003 - Third Excavation Campaign, a preliminary report.

22 octobre: Ludivine PROVOST (doctorante, université Paris-III, boursière de l'EFEO), Les énigmes de la période "post-Bayon".

10 novembre: Gerdi GERSCHHEIMER (EFEO/EPHE), Le "Corpus des inscriptions khmères » : état des lieux et perspectives.

3 décembre: Michael D. COE (Professor of Anthropology, Emeritus, Yale University), Maya and Khmer: studying monsoon forest civilisations.

22 décembre : Jeffrey HIMEL (Independent Researcher), Delusions and Grandeur - A Comparison of Khmer Rouge and Ancient Large-Scale Land and Water Management Techniques.

Liste des conférences 2004

9 janvier: Prof. Rethy K CHHEM (Faculty of Medicine, University of Western Ontario, Canada), Histoire de la médecine à Angkor: institutions et pratiques médicales sous Jayavarman VII (1181-1220).

12 janvier : Pamela GUTMAN (University of Sydney), The Art and Architecture of Arakan and its Southeast Asian Context.

23 janvier: Surat LERTLUM (Asian Institute of Technology, Bangkok), Remote Sensing and GIS for Archaeological Applications in Thailand: Case Studies of Royal Road from Angkor to Phimai, the Study at Sukhothai World Heritage Site, and Ayutthaya's Multi-temporal GIS Database.

30 janvier : Damian Evans (Archaeologist, University of Sydney), Putting Angkor on the Map: The Discovery and Analysis of Settlement Structure Using Remote Sensing and GIS.

7 février : Roxanna Brown (Southeast Asian Ceramics Museum, Bangkok University), New Data from Shipwrecks: Five Phases for Thai Ceramics Production c. 1380-1580.

16 février: Christian DARLES (Enseignant-chercheur à l'École d'architecture de Toulouse), Architecture et Ville, au Yémen : une histoire de projets. Commentaires sur la continuité et la permanence des morphologies urbaines et des types architecturaux depuis 25 siècles.

19 février : Louise Allison CORT (Curator for Ceramics, Freer Gallery of Art and Arthur M. Sackler Gallery Smithsonian Institution, Washington, D.C.) \& Leedom LEFFERTS (Emeritus Professor of Anthropology from Drew University, New Jersey), The Tai Stoneware Tradition: from Present to the Past. 
2 mars : Dominique SoUTIF (doctorant à l'Université Paris-III, Sorbonne Nouvelle), Le temple khmer " vivant".

23 avril : Patrice LECOQ (maître de conférences, Université de Paris-I, PanthéonSorbonne), Aperçu des grandes civilisations de l'Amérique du Sud; l'exemple de Tihuanacu (600-1000 apr. J.-C.) en Bolivie.

20 mai : projection privée du film L'ODYSÉE DE L'ESPÈCE, un film de Jacques Malaterre, sous la direction scientifique d'Yves Coppens (professeur au Collège de France). Débat animé par Fabrice Demeter (paléoanthropologue au Collège de France), conseiller scientifique du film.

26 mai : projection privée de BODY JARS, un film de Tim Tony (2003, 47'), Prod. Becker Entertainment for National Geographic Channel (Australie). La projection a été suivie d'un débat animé par Fabrice Demeter, paléoanthropologue au Collège de France.

23 juin : Arlo GRIFFITHS (Indologist, University of Groningen), About Languages in India (and some connections with South East Asia).

7 juillet : Ken TAYLOR (Emeritus Professor, University of Canberra), Borobudur, Cosmic Mountain of the Perfect Buddhas: World Heritage and Dilemmas of Conservation and Interpretation.

30 septembre : PHIN VICHEAR Sachara, HENG Than, CHHAY Rachna (APSARA, Siem Reap) \& Christophe POTTIER (EFEO), Excavations on a prehistoric site in the western Baray.

9 novembre: Ang CHOULÉAN (ethnologue, chercheur associé de l'EFEO), La fête des morts.

5 octobre: Simon WARRACK (Chief Conservator for the GACP), The Return of the Obelisk of Axum. From Ethiopia to Italy ... and back? 